\title{
Oman's Ability to Attract FDI: Dunning Instrument Survey Analysis
}

\section{Capacidad de Omán para atraer IED: análisis de la encuesta de instrumentos Dunning}

\author{
Mohammed Ali Bait Ali Sulaiman \\ Salalah College of Technology, Salalah, Sultanate of Oman, Oman \\ ORCID: https://orcid.org/0000-0003-1626-8362 \\ Seemab Rana \\ Salalah College of Technology, Salalah, Sultanate of Oman, Oman \\ ORCID: https://orcid.org/0000-0003-0849-4634

\section{Muhammad Salman Shabbir} \\ College of Commerce and Business Administration, Dhofar University, Sultanate of Oman, \\ Oman \\ ORCID: https://orcid.org/0000-0002-0796-0456
}

Received 02-12-20 Revised 02-25-20 Accepted 06-13-20 On line 06-29-20

*Correspondence

Email: Ssv@ores.su
Cite as:

Bait Ali Sulaiman, M.A., Rana, S., \& Shabbir, M.S. (2020). Oman's Ability to Attract FDI: Dunning Instrument Survey Analysis. Propósitos y Representaciones, 8 (SPE2), e640. Doi: http://dx.doi.org/10.20511/pyr2020.v8nSPE2.640 


\section{Summary}

The purpose of this paper is to establish the extent to which Oman is capable of attracting more of the foreign direct investment (FDI) through dunning model instruments. The results of the analysis are determined using responses provided by the foreign companies concerning the features of Oman. Data used in the analysis were collected from 30 different foreign companies operating in Dhofar region of Oman using questionnaires. ANOVA test, Chi-square tests and Friedman's mean ranks were carried out to test the homogeneity and magnitude of the responses given by the respective companies. the findings of Effect size analysis indicate that Oman's system structure, Policy framework, provision of facilities and ease of access are strongly contributing in attracting FDI. However, Oman needs to focus on the improvement of business friendly environment and compassionate policy formation in favor of investors.

Keywords: Foreign Direct Investments; Oman; Investment Incentives; Dunning Model; Dhofar.

\section{Resumen}

El propósito de este documento es establecer en qué medida Omán puede atraer más inversión extranjera directa (IED) a través de instrumentos modelo de reclamación. Los resultados del análisis se determinan utilizando respuestas proporcionadas por compañías extranjeras con respecto a las características de Omán. Los datos utilizados en el análisis se obtuvieron de 30 empresas extranjeras diferentes que operan en la región de Dhofar de Omán mediante cuestionarios. Se realizaron pruebas ANOVA, pruebas de Chi-cuadrado y rangos medios de Friedman para probar la homogeneidad y la magnitud de las respuestas dadas por las respectivas compañías. Los resultados del análisis del tamaño del efecto indican que la estructura del sistema, el marco de políticas, la provisión de instalaciones y la facilidad de acceso de Omán están contribuyendo fuertemente a atraer IED. Sin embargo, Omán debe centrarse en mejorar el entorno favorable para las empresas y la formación de políticas compasivas a favor de los inversores.

Palabras clave: Inversiones Extranjeras Directas; Omán; Incentivos De Inversión; Modelo Dunning; Dhofar.

\section{Introduction}

In recent past, many developing countries government have been looking the Impact of foreign direct investment on the economic development. Most of them see it as the key of the economic development success. Due to these issue, third world countries have raised an intense competition to attract foreign direct investment into their country (Abdallah, 2015). According to the information from the research made in the past, these foreign investors are given attractive incentives by the host government to encourage them to invest more in the country. This act marries the practices in Oman which bases its plans of economic development, political rhetoric and the prospect of future social development on its potential to attract more of the foreign direct investment (Abdallah, 2015). Information available on the ability of Oman to attract foreign direct investment brings about the need for research since all other countries in the Middle East region does not attract a number greater than $3 \%$ of the foreign direct investment in the world (AlHamadi et al. 2007). Compared to other Gulf Co-operation Council (GCC) countries, Oman appeared to perform better in the 1990s (Al-Hasan, 2012).

Oman is a small state that produces oil with a population of approximately over 2 million people. Before oil was discovered in the state around the 1960 s, much of its population $90 \%$ were working in agriculture sectors while the rest of the population $10 \%$ were engaged in activities such as fishing and trading. However, after oil was discovered in the 1960s, the economy of Oman gets transformed because of oil export. Due to the financial surplus that resulted from oil revenue 
around the 1970s and 1980s. Oman was able to finance local development programs without inputting foreign capital. Oman had poor entry behavior regarding foreign entry and ownership procedural requirement. Taking an example of both 1974 and 1978, the law governing investments in Oman prioritized giving local investor's better chance than foreign investors and and Oman policy makers were less interested in obtaining foreign capital ${ }^{1}$. Increased export of oil resulted in fall in prices of the oil, which lead to the deficit in 1998 of around 122 million from $1973^{2}$. This deficit made Oman realize it cannot hide from globalization. Oman also realized that it cannot find a way to venture into World Trade Organization (WTO) without taking hand in lowering tariffs and taking other obligations required for WTO membership such as conducive environment for foreign direct investment. Consequently, Oman started incorporating new technology and information while securing the existing relevance technology. Oman is attempting to widen its economy and lower as much as possible its normal routine of oil dependency as the key source of its income by opening doors to foreign investors.

Like all economies, Oman's economy is also evaluated for FDI by different investment promoting international organizations. This study has compiled some latest statistics regarding economic freedom (EF) indices and ease of doing business (EDB) indices for Oman. Oman's score for EF indices are tabulated for last three years in Table A2 (see appendix). The overall EF score values were better in 2016 and 2015 but have decreased in 2017. Score for individual sub determinants for EF index is presented in same table for comprehensive evaluation of Oman's current state in the world. Another index that is helpful to examine FDI attractiveness ability is the EDB index. EDB sub-indices for Oman are assembled in Table A3 (see appendix). Over all rank gained by Oman in 2017 is 66 among 141 countries which implies more than 50\% countries are in better position than Oman to attract FDI from the world. Thus, it increases number of challenges for Oman to compete with other economies. Oman does not provide incentives in order to protect investor and in dealing with construction permits which are very important determinants for FDI. EDB ranked Oman in least suitable countries for FDI due to these two factors. Tax incentives are identified as big attraction for foreign investors to bring FDI in Oman but only few features like this are not sufficient to attract large share of FDI where the other regions have improved far better than Oman in their policies and economic reforms to prove them more business friendly regions in the world. Other key determinants are listed in Table A3 along with their scores for Oman which raise questions on the rigidity of stratagem and policy measurements in recent era. Fig 1 depicts Oman's FDI inflows in comparison with the world and other regions under investigation.

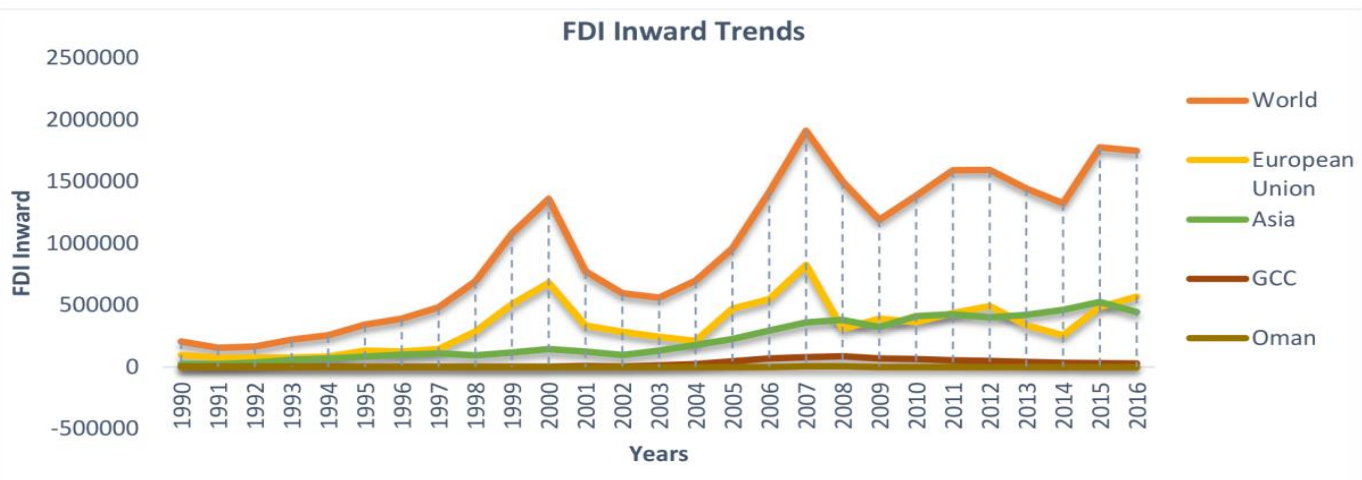

Figure 1. FDI Inward Trends. Source: Writer's Calculation with Data from World Investment Report (2017)

\footnotetext{
${ }^{1}$ Reported by Gulf Organization for Industrial Consulting (GOIC) in 2001 when Oman was found discouraging foreign ventures through thorough screening and restrictions enforced to various sectors to protect its domestic producers and industries.

${ }^{2}$ Stated by National Centre for Statistics Information (NSCI) in 2014.
} 
Dunning model (also referred as Eclectic Paradigm or OLI model), in this perspective, is a rich and robust framework to retrieve guidance for any economy ${ }^{3}$. Eclectic Paradigm (Dunning, 1993), is a comprehensive framework to explain patterns and the level of international methods of production that are undertaken by firms engaged in foreign direct investment ${ }^{4}$. Suggestions from eclectic paradigm is that the level of production a firms or nationality is dependent on how much they can possess or gain access to, technological know-how, available resources or other means of income generating activities that are not accessed by their competitors which is also known as ownership advantage (Verbeke and Yuan, 2010). On the other hand, given that a certain firm possess ownership advantage, to be involved in FDI, then the firm it must take that advantage to manage and own such value-adding activities (Dunning, 2014). In other words, Dunning model identifies areas where the host country needs to emphasize in order to get capital inflow and the foreign investor needs to asses the feasibility and gains of investing in the host country (Dunning, 2000).

Oman has a free and open economy with no limitations to the activities carried out by foreign investors but Oman's attempt to create a conducive environment ${ }^{5}$ for the investors is a pre-requisite factor to promote foreign direct investment (Pauceanu, 2016). Study on the factors determine the ability to attract FDI in Oman indicates that there are several factors that might determine FDI location decision. This can range from market size to the level of security in the state. According to various studies carried out by different researchers such as Cristina and Dunning (2014), Cantemir (2012), Forstenlechner and Rutledge (2011), Faeth (2009), James (2009), Lim (2008), Dunning (2008) and Mina (2007), it is noted that determinants like the level of infrastructure, geographical location and the cost of transportation of the both raw materials and manufactured products, tax incentives, policies put forward by the host country concerning investments and the level of competition by the industries in host country market, play significant role in attracting FDI.

In developing countries, per capita GDP is the most determinant factor in evaluating the ability to attract foreign direct investment. Matwally (2004) found positive correlation between the level of FDI attraction and the level of national income in the host country. Studies carried out in different regions showed that there is a strong correlation between the number of foreign investment and the market size provided by the host country (Dunning, Kim and Park, 2008). Keeping in view other aspects of the economy, constant, availability of resources, cost of production, accessibility of raw materials and the supply of labor are also claimed to have a significant impact on decisions relating to foreign direct investment (UNCTAD, 2010). The inflow of foreign direct investment can also be determined by the level of political stability. This is because political instability will reduce the interest of the foreign investors into the country translating to a low level of foreign direct investment (USAID, 2005). Therefore, they will dare to take risk of investing in a country that is politically stable. Literature also reveals that the lower the cost of labor the more attractive the country is to access more foreign direct investment. These factors differ from country to country which results in the different inflow of foreign direct investments to different developing countries. (World Bank Group, 2010). Given the geographical location and cultural proximity of the states to Oman, we exclude factors that could mean diminutive to the companies of GCC.

\footnotetext{
${ }^{3}$ Introduced by Dunning (1958) when first comprehensive study was conducted for UK to analyze the effects of FDI in host country. Eclectic Model (OLI) was first introduced in 1976 and then was refined several times during 1988 and 1993. Where, O stands for Ownership advantages, L stands for Location advantages and I stands for Internationalized advantages.

${ }^{4}$ Further extensions of Eclectic Paradigm model can be viewed in Dunning (2015).

${ }^{5}$ Oman should sideline all restrictions pertaining to the entry of local ventures and remove ownership barriers in various sectors as well as lower the minimum capital required as explained by Gulf Organization for Industrial Consulting (2001)
} 
The main objectives of the study try to establish; the extent of the attractiveness of Oman's policy framework, the level of Oman's facility provision, Oman's accessibility and the structure of the system applied by Oman. In other words, this study tries to investigate what Oman has done on matters pertaining to the provision of incentives to foreign investors and the areas that are not yet improved in this regard. Thus, this research explores steps made by the Oman government to attract foreign direct investment. Measurement of the steps is done according to dunning model framework and interpretations. Additionally, recent indicators relevant to Oman's features are incorporated in this design. The conceptual frame work is designed in Fig. 2. where, dunning model is presented through four of its instruments. Each instrument comprises further sub instruments for in-depth analyses of Oman's ability.

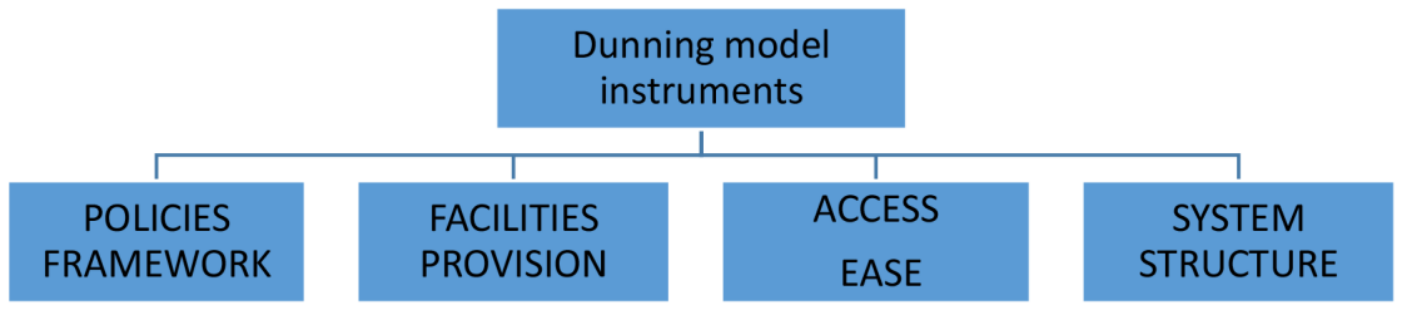

Figure 2. Dunning Model Instrument Conceptual Framework. Source: Writer's Formulation

Faeth (2009) in her study presented a review of nine theoretical models of FDI which include; early studies of FDI determinant, neoclassical trade theory of FDI determinant, ownership advantage, aggregate variable, international framework advantage, vertical and horizontal FDI models, the knowledge capital model, diversified FDI, and policy variable. She reviewed some empirical studies to explore important of stated determinates and concluded results based on the theoretical models. Sethi et al. (2003) provided a rationale of changing trends in the flow and determinant of FDI. This study used generic descriptive models in the analysis to explain the trends of FDI flow. The study carried out by Pantelidis and Nikolopoulos (2008) investigated FDI attractiveness in Greece compared to other countries in Europe. This paper explored a set of factors that determined the level of attractiveness in Greece in the last few years. They used both econometric model and comparative index to evaluate the difference in the level of attractiveness of the country.

A study by Lim (2008) examined how government effort through investment promotional agency (IPA) influences foreign direct investment (FDI) inflows. The paper used structural equation analysis and argued that the mediator variable such as investment promotion affects FDI environment in the host country. Chidlow et al. (2009) examined how location determines the inflow of FDI in Poland. They used surveys to collect data from the online questionnaire and multinomial logit model in the analysis of the investor's characteristics. The findings of Mukim, Megha and Nunnenkamo (2010) for India and Mina (2007) for GCC are also consistent with their views. Cristina and Cantemir (2012) also analyzed how public officials influenced location decision for FDI in both central and eastern European countries on bases of the attractiveness of policies. In their study, they used the TOPSIS ${ }^{6}$ method in calculating the degree of attractiveness.

Wagle (2010) examined the effects of FDI specific regulations developed and imposed by host countries. He explained that the restriction imposed by any government on startup of foreign venture disrupts the confidence of investor and adversely affects FDI inflow. Shahzad et al. (2016) employed variance decomposition and impulse response analysis to find the effects of terrorism on FDI of Pakistan. This study derived results by comparing pre and post $9 / 11$ period

\footnotetext{
${ }^{6}$ Technique of order preference by similarity to ideal solution is used to calculate degree of attractiveness on any economy.
} 
and concluded that terrorism issue in Pakistan has caused significant damage to FDI inflow. Moosa (2009) assessed the root causes of FDI flow to 18 MENA countries. He employed extreme bound analysis through linear regression model and highlighted education and research \& Development as core determinates of FDI inflow. Woo (2010) studied the impact of corruption on FDI attractiveness in 90 countries. A panel data analysis is conducted over the period of 19842004. He found that corruption has harmful effect of FDI and democratic countries attract less FDI and dictatorship countries attract more FDI because of corruption level.

Narula and Dunning (2000) argued on the importance of availability of assets to attract multi-national enterprises because these enterprises have become knowledge intensive and looked for better alternative opportunities to establish their business (See also Dunning (2000) for further evidences). Verbeke and Yuan (2010) and Tallman (2003) has employed Dunning Eclectic model to explain the strategic policies adopted by multinational companies in a knowledge economy. These studies presented management analysis and strategies adopted by international companies to gain advantages. Tuluce and Dogan (2014) presented detailed views about the strategic decisions of international enterprises for foreign investment.

Sadik and Blbol (2001) highlighted the importance of FDI for Arab development and dictated that state of technology can turn the flow of FDI towards Arab countries. Mellahi et al. (2003) studied the economy of Oman and attempted to find the motives behind FDI. They argued that the economy like Oman needs to reformulate policies regarding business startup procedures because it's a big obstacle for investor to proceed. Another analysis by Pauceanu (2016) for Dhofar governorate, debated that low cost of doing business and big market size is necessary in Oman while some incentives such as creation of free zones and lower tax rates are already offered by Oman government to boost FDI. This study utilized government reports and interviews with government officials to draw conclusion. Ibrahim and Abdel-Gadir (2015) presented another analysis of Oman' FDI. They examined period 1980 to 2013 and found that inflation rate, market size and government expenditures are the main determinants influencing FDI inflow. Alraja, Hammami and Samman (2016) stressed upon the necessity of ICT development in Oman because it is the most appealing factor for the foreign investors. This study also argued that Oman government should ease it policies for ICT investors to enhance ICT development.

\section{Data Description and Portrayal}

The data used in this study is collected using questionnaire from 30 different foreign companies functioning in Dhofar region of Oman. Then the questionnaire data variables were analyzed empirically. Data is organized and presented in both graphical and tabular forms using excel and SPSS. Analysis is done to establish the objectives of the study by the testing hypothesis. To provide detailed examination, inward FDI performance (IFPI) is computed for three subsequent years in Table A1 (see appendix). Table A1 displays FDI inflow, GDP and IFPI for Oman and three another region. These macro indicators are retrieved for 2016-2018 to reveal recent variations in FDI and its performance in host country. Oman has shown slight downfall in FDI inflow and for GDP. But interestingly the overall performance index (IFPI) has improved in 2017 as compared to previous years. GCC region has also shown enhancement but the for Asia and EU regions, IFPI has confronted downward movement calculated from UNCTAD data. In this part of the paper we are presenting descriptive analysis according to the objectives of the study. The results are generated from analysis of the responses given by thirty different companies of Dhofar region of Oman. Percentage responses are given to test three main ingredients of Dunning models while descriptive statistics that was used involved respondent's frequency and percentage distribution tables because research variables were measured in nominal level measurement. 


\section{Companies' Country of Origin}

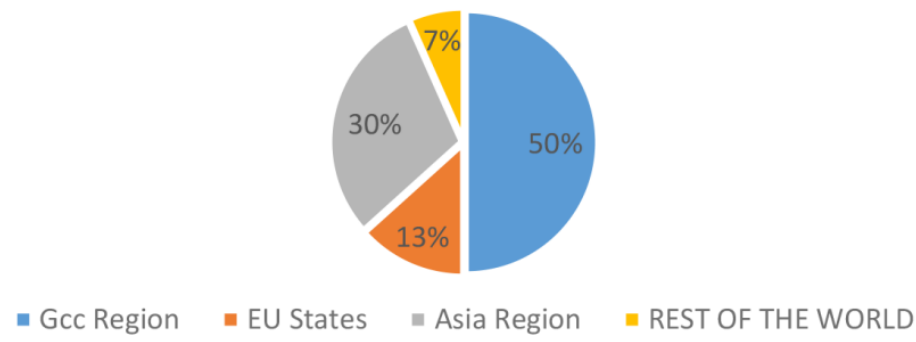

Figure 3. Company's Country of Origin. Source: writer's calculation from survey data

Respondents were asked to indicate their company according to the country of origin. According to the analysis done in Fig. 3, most of the respondent 50\% indicated that they originate from Gulf Co-operation Council (GCC), 30\% of the respondent indicated they originate from the Asian region, $13 \%$ agreed that they originate from the Europe States while 6.9\% agreed they originate from the rest of the world.

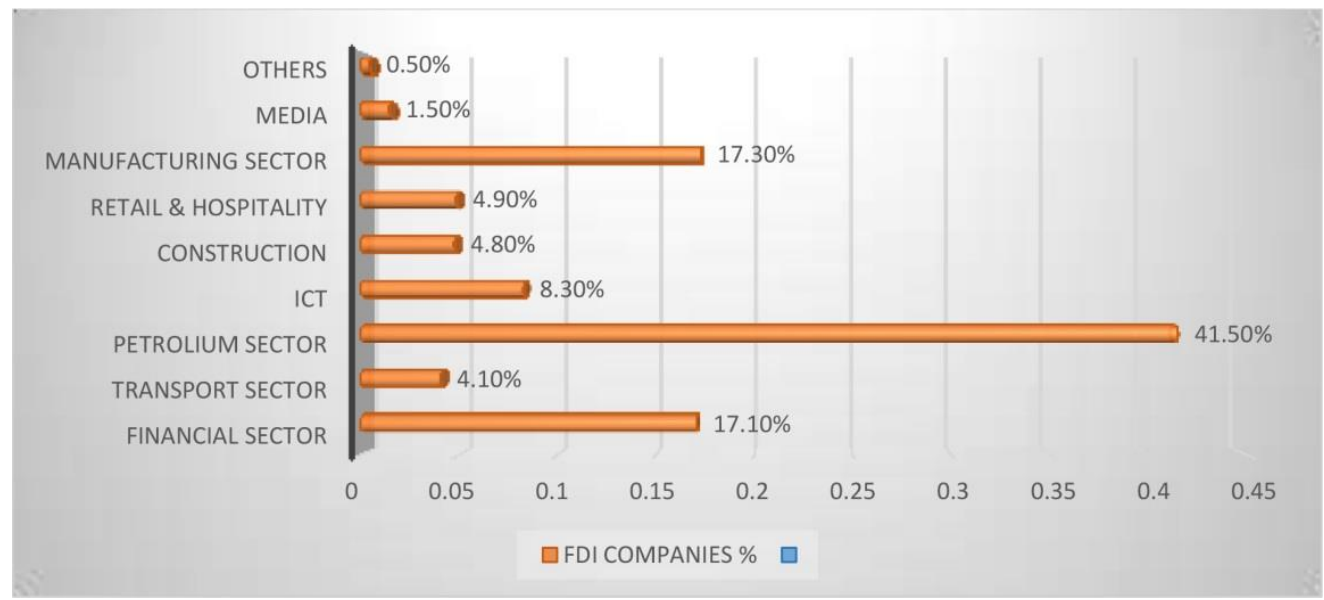

Figure 4. Sector Wise Contributions of Companies in Overall Oman Source: Oman Investment and Finance Co. (OIFC)

This study accessed sector-wise investment contributions of these companies in Overall Oman as shown in Fig. 4 above. Analysis indicated that all (FDI) companies contributed $41.5 \%$ in petroleum sector, $17.30 \%$ in the manufacturing sector, $17.1 \%$ in financial sectors, $8.3 \%$ in the information communication technology, $4.9 \%$ in retail and hospitality, $4.8 \%$ in construction, $4.1 \%$ in transport sector, $1.5 \%$ in media while $0.5 \%$ in other areas.

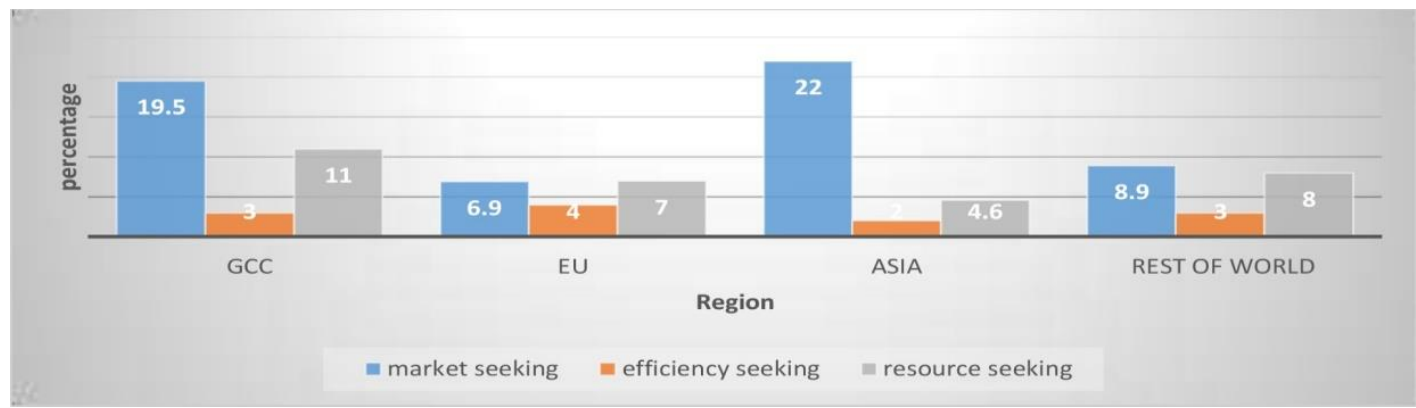

Figure 5. Reasons of Investment in Oman: Market, Efficiency and Resources. Source: writer's calculation from survey data 
Respondents were asked to indicate the reasons for investing their company in various sectors in Oman (see results in Fig. 5). The reasons for investments were asked in the survey because they form part of dunning model. Therefore, according to the analysis done, majority of the respondent (19.5\%) in Gulf Co-operation Council (GCC), (6.9\%) European States, (22\%) Asian region and $(8.9 \%)$ the rest of the world indicated that were seeking to expand their market while minority of the respondent (3\%) in Gulf Co-operation Council (GCC), (4\%) European States, $(2 \%)$ Asian region and (3\%) of the rest of the world indicated that they were seeking for efficiency of their product in Oman.

The main objectives of the study try to establish; the extent of the attractiveness of Oman's policy framework, the level of Oman's facility provision, Oman's accessibility and the structure of the system applied by Oman. Likert scale-based count of 30 respondent companies possessing demographic and sectoral distinctiveness is calculated using SPSS to get the insight of their viewpoint concerning main objectives of the research. Four dunning model instruments were analyzed as shown below in Table 1 .

Table 1.

Percentage response for dunning model instruments by 30 companies

\begin{tabular}{|c|c|c|c|c|c|}
\hline Instruments & Response & GCC & EU & ASIA & $\begin{array}{l}\text { REST OF } \\
\text { WORLD }\end{array}$ \\
\hline \multirow{3}{*}{$\begin{array}{l}\% \text { Response } \\
\text { for Policies }\end{array}$} & Strongly agree / Agree & 19.5 & 6.9 & 22 & 8.9 \\
\hline & Indecisive & 3 & 4 & 2 & 3 \\
\hline & $\begin{array}{c}\text { Strongly disagree / } \\
\text { Disagree }\end{array}$ & 11 & 7 & 4.6 & 8 \\
\hline \multirow{3}{*}{$\begin{array}{l}\% \text { Response } \\
\text { for Access }\end{array}$} & Strongly agree / Agree & 15 & 12 & 23 & 3.3 \\
\hline & Indecisive & 3.3 & 4 & 5 & 6 \\
\hline & $\begin{array}{c}\text { Strongly disagree / } \\
\text { Disagree }\end{array}$ & 8.7 & 9.4 & 7.2 & 3 \\
\hline \multirow{3}{*}{$\begin{array}{l}\text { \% Response } \\
\text { for Facilities }\end{array}$} & Strongly agree / Agree & 32 & 16 & 5 & 11 \\
\hline & Indecisive & 1.1 & 3.2 & 6 & 7 \\
\hline & $\begin{array}{l}\text { Strongly disagree / } \\
\text { Disagree }\end{array}$ & 5.4 & 2.9 & 4.4 & 5.9 \\
\hline \multirow{3}{*}{$\begin{array}{l}\% \text { Response } \\
\text { for System }\end{array}$} & Strongly agree / Agree & 31.3 & 16.5 & 10.5 & 16.1 \\
\hline & Indecisive & 1 & 3 & 1 & 5 \\
\hline & $\begin{array}{c}\text { Strongly disagree / } \\
\text { Disagree }\end{array}$ & 5.7 & 4.4 & 3.6 & 1.8 \\
\hline
\end{tabular}

Source: writer's calculation from survey data

From the analysis done majority of the respondent $19.5 \%$ from Gulf Co-operation Council (GCC) countries agreed that Oman's policy framework determine the level of attractiveness of the foreign direct investment, majority $6.9 \%$ of the EU agreed with GCC remarks, $22 \%$ of the respondent from Asian supported the statement then backed by $8.9 \%$ of respondent from the rest of the world.

The study also tried to establish how Oman accessibility determines the level of foreign direct investment attractiveness. According to the analysis done, it is noted that majority $15 \%$ of respondent from Gulf Co-operation Council (GCC) countries agreed that Oman's accessibility determined the level of FDI attractiveness which was supported by majority from EU and Asia 
with $12 \%$ and $23 \%$ respectively while majority $6 \%$ from the rest of the world where indecisive on the impact of Oman accessibility to level of foreign direct investment attractiveness.

Further, the study tried to evaluate the impact of facility provision by Oman government to the level of the foreign direct investment attractiveness. The analysis done shows that the four regions; Gulf Co-operation Council (GCC) countries, EU, Asia and the rest of the world agreed with the statement that provision of the facilities by the government encourages more foreign direct investment as shown by $32 \%, 16 \%, 5 \%$ and $11 \%$ respectively.

High ranks imply that the existing foreign investment companies are satisfied from prevailing government steps taken to provide conducive environment for the growth of FDI. According to companies' responses, Government role and policies is ranked least which reflects more improvement to satisfy foreign investors. Along with this inter assessment of sub ranks, Intra assessment is also designed for better evaluation of the results obtained from companies' perceptions with the results retrieved from world economic forum. WEF index (see Global competitiveness report, 2017-18) is added in same table (Table A4) of mean ranks only for the sub instruments under examination in this study for 2018.

WEF index reports different results from mean ranking order and ranked for more than 140 countries. According to WEF index, tax incentives, corruption situation and political stability has contributed a lot to give top position among 141 countries. Law and order situations, institutional standard and social climate are appealing points to attract FDI and gives much better position to Oman among top 30 countries of the world. Industrial development policies and labor cost ranking for Oman is still far behind and rank Oman amongst least favorable countries for FDI opportunities. Skilled labor access and foreign market access still appear as big obstacles on the way to derive big share of FDI inward. Financial facilities need a lot more improvement in this process along with other challenges like insufficient local market access and lacks investment opportunities at global level.

By using SPSS, ANOVA Test is employed to test our hypotheses further effects are examined through effect size calculation. Additionally, Pearson's Chi-Square statistics are calculated to test the hypothesis of the association between variables on the bases of demographic features. P-value of the test is plotted in the table below along with their separate degree of freedoms to compare it with significant level. Alpha $=0.05$ was used to conclude whether the variables are independent. Chi-square test is used because we have more than two categorical variables from a single population (explained in Fillat-Castejón et al., 2008). 
Table 2.

Chi-Square Analysis of Dunning Instrument Model from SPSS Output.

\begin{tabular}{lcc}
\hline Variables & Chi-Square Statistics & P-Value \\
\hline $\begin{array}{c}\text { POLICIES FRAMEWORK } \\
\text { Region }\end{array}$ & $23.31^{*}$ & 0.02 \\
\hline $\begin{array}{c}\text { FACILITIES PROVISION } \\
\text { Region }\end{array}$ & $26.14^{*}$ & 0.01 \\
\hline $\begin{array}{c}\text { ACCESS EASE } \\
\text { Region }\end{array}$ & 0.04 \\
\hline $\begin{array}{l}\text { SYSTEM STRUCTURE } \\
\text { Region }\end{array}$ & 0.04 \\
$\begin{array}{l}* \text { indicates significance of chi-square test values at 5\% level. Source: writer's calculation from survey } \\
\text { data }\end{array}$ & $21.69^{*}$ \\
\end{tabular}

According to the analysis given above in Table 2, it is noted that policies and framework used in Oman had a significant impact on the ability to attract more of foreign direct investment (chi stats $=23.31 *$ ) and $(0.02 *)$ which significantly promote the growth of the economy in Oman, hence we fail to reject null hypothesis that there is an association between provision of the policy framework and Oman's ability to attract FDI, this implies that dunning model instruments had significant impact on Oman's economic policy. On the other hand, provision of facilities in the region significantly influenced the ability of Oman to attract more foreign direct investment (chi stats $=26.14 *)$ and $(0.10 *)$ which significantly contribute to the level of growth of Oman economy, this concurs with null hypothesis that there is an association between provision of facilities and Oman's ability to attract FDI.

In addition, accessibility of Oman was significantly associated with the ability of Oman to attract more foreign direct investment in the region (chi stats $\left.=21.69^{*}\right)$ and $\left(0.04^{*}\right)$. This implies that its accessibility attracted more of FDI hence enhancing the growth of Oman economy, therefore, in the case we fail to reject the null hypothesis that there is an association between accessibility of Oman and Oman's ability to attract FDI. Furthermore, the structure of the system used in Oman was significantly (chi stats $=21.38^{*}$ ) and $\left(0.04^{*}\right)$ associated with its ability to attract more of FDI which play a major role in promoting its economy. Hence, we fail to reject the null hypothesis and conclude that there is an association between system structure and Oman's ability to attract FDI.

Table 3.

Friedman Test for Dunning Model Instruments

\begin{tabular}{ccc}
\hline $\mathrm{N}^{\circ}$ & $\begin{array}{c}\text { Dunning Model Instruments to Asses Oman's Ability for } \\
\text { Attracting FDI }\end{array}$ & Rank \\
\hline 1 & Policies Framework & 2.58 \\
\hline 2 & Facilities Provision & 2.47 \\
\hline 3 & Access Ease & 2.38 \\
\hline 4 & System Structure & 2.57 \\
\hline
\end{tabular}

Source: writer's calculation from survey data

To determine whether foreign firms perceive location-specific motives differently in Oman, Friedman's test was used (Table 3). Friedman's test is a non-parametric procedure which tests whether two or more variables come from the same distribution. Applying the test on the four dunning model instruments in this research, the test indicated that our dunning subinstrument were rated differently. 
The overall Friedman's Mean Ranks (FMR) and Means of the ability of Oman's to attract FDI are shown in Table A1 in the appendix. These results reveal that policy framework was highly satisfactory $(F M R=2.58$, mean $=14)$ and structure of the system $(F M R=2.57$, mean $=13)$ which implies they are the two most important instrument that determines the ability of Oman's to attract FDI. Contrary to expectations, facility provision to FDI $(F M R=2.47$, mean $=8)$ and ease of accessibility of Oman $(\mathrm{FMR}=2.38$ mean $=7$ ) appear to be unsatisfactory instruments in determining the ability of Oman to attract FDI, hence they are the least implemented policies respectively.

To check significance empirically, ANOVA test ${ }^{7}$ is employed for each instrument separately and then, Effect size ${ }^{8}$ is also computed to check each instrument effect individually. Results of ANOVA test and Effect size are exhibited in Table 4. Four hypotheses are tested through F-statistics obtained through ANOVA process against P-value i.e. 0.05. If P-value is less than 0.05 , the null hypothesis is rejected and instruments will be said statistically significant. Effect size is determined according to thumb rule criteria.

Table 4.

ANOVA Test and Effect Size Results for Dunning Model Instruments

\begin{tabular}{ccccccc}
\hline Instruments & Observations & Mean & SD & F-ratio & Sig. & $\begin{array}{c}\text { Effect } \\
\text { Size }\end{array}$ \\
\hline Policies Framework & 149 & 0.116 & 0.74 & 6.31 & 0.034 & 0.11 \\
\hline Facilities Provision & 148 & 0.0729 & 1.24 & 8.82 & 0.005 & 0.23 \\
\hline Access Ease & 120 & 0.055 & 0.89 & 7.96 & 0.019 & 0.09 \\
\hline System Structure & 176 & 0.0921 & 0.51 & 4.47 & 0.001 & 0.19 \\
\hline
\end{tabular}

Note: Significance level is at $5 \%$

F-calculated is observed against critical values of F-statistics to determine the rejection of hypothesis. Effect size is investigated through thumb rule: Small effect if value $>0.01$, Medium effect if value $>0.06$, Large effect if value is $>0.14$

ANOVA test findings indicate rejection of null hypothesis for each instrument at 0.05 level of significance. All F-stat values are high showing the selected relationship is statistically significant and all four instruments affects Oman's FDI. Acceptance of alternative hypotheses refers that the mean values in each group are different meaning, association between variables exist but type of association or effect size of each instrument is not distinguished. To serve the purpose, Effect size is also computed. Effect size results reveal that effect of policy framework and access ease is medium on FDI attraction. Facility provision got the highest effect to attract FDI and System structure is found lees effective for Oman's FDI inflow. There fore all instruments are found affecting FDI flow in Oman.

The overall results of this study conclude that policy framework applied by Oman are satisfactory in attracting more foreign direct investment and its effect is medium. On the other hand, a structure of the system applied by Oman have the significant impact to the growth of Oman economy, but facilities provided by Oman and its accessibility are found unsatisfactory in attracting foreign direct investment but their effect of FDI is high. Therefore, Oman government is supposed to improve facilities provided to increase the inflow of foreign direct investment.

\footnotetext{
${ }^{7}$ Our primary data satisfies the assumption s of ANOVA test such as each observation is independent and our sample size is greater than 25 i.e. normally distributed. Thus, F-statistic follows F-distribution.

${ }^{8}$ Effect size is calculated from two sum of squares (SS) i.e. SS (between) and SS (with in).

Effect size $=$ SS $($ between $) /$ SS (between) + SS (within)
} 


\section{Conclusion}

This study employed empirical testing of hypotheses through, Chi-square, ANOVA test, Effect size and Friedman's Mean ranking to draw conclusion. The findings identified that there was an association between provision of the policy framework and Oman's ability to attract FDI, this implies that dunning model instruments had a significance and strong impact on Oman's economic policy. On the other hand, the research also concurs with the null hypothesis that there is an association between provision of facilities and Oman's ability to attract FDI where, facility provision is found highly influential for FDI attraction but provision quality is not satisfactory according to foreign investors so it needs improvement. In addition, the study reveals that there is an association between accessibility of Oman and Oman's ability to attract FDI with a medium effect. Nevertheless, the study also concludes that there is an association between system structure and Oman's ability to attract FDI and its influence on FDI is very strong which indicates that Oman government must focus on reforming structure in favor of Foreign investors. From the point of view of foreign investors, Oman has made a lot of effort in ensuring they raise the level of foreign direct investment into their economy. Data analysis reveals that policies and framework, provision of facilities, accessibility and structure of the system contribute significantly to Oman ability to attract more foreign direct investment which in turn add significant impact to the growth of its economy.

Fortunately, an encouraging comment Oman has received from World Investments Report (WIR) that Oman's government is steadfast to ensuring their strategies are market-oriented and to attract more FDI. But simultaneously, several determinants ${ }^{9}$ have been identified those can influence future FDI activity in Oman and for other regions as well. In all terms, Oman requires keen considerations while formulating policies specifically for the FDI carrying and supportive sectors.

\section{References}

Abdallah, A. (2015). A critical analysis of foreign capital investment law in Oman. The Journal of World Investment and Trade, 16(3), 506-531.

Al-Hamadi, A.B., Budhwar, S., \& Shipton, H. (2007). Management of human resources in Oman. International Journal of Human Resource Management, 18, 100-113.

Al-Hasan, H. (2012). Labor Market Politics in Bahrain. Labour Market, Unemployment, and Migration in the GCC: 117-57.

Alraja, M.N., Hammami, S., \& Al Samman, H.M. (2016). Investment in ICT in Developing Countries: the effect of FDI: Evidences from Sultanate of Oman. International Journal of Economics and Financial Issues, 6(4).

Business, D. (2010). Doing Business (2011). Making a difference for entrepreneurs. Washington, DC: World Bank and International Finance Corporation (IFC).

Business, G. (2001). Oman SWOT Report: Private sector led growth is one way but is Oman ready?. Gulf Business, 5(9), 46-51.

Chidlow, A., \& Salciuviene, L., \& Young, S. (2009). Regional determinants of inward FDI distribution in Poland. International Business Review, 18(2), 119-133.

Cristina, P.O., \& Cantemir, C.A. (2012). Attractiveness of public policies for FDI in Central and Eastern European countries. The Annals of the University of Oradea, 61.

Dunning, J.H. (1993). Trade, location of economic activity and the multinational enterprise: A search for an eclectic approach. The theory of transnational corporations, 1, 183-218.

Dunning, J.H. (1998). Location and the multinational enterprise: a neglected factor?. Journal of international business studies, 29(1), 45-66.

\footnotetext{
${ }^{9}$ Those factors are: regional economic integration, commodity price hike, austerity policies, financial regulations, policy rigidity, corporate and external factors and sovereign debt.
} 
Dunning, J.H. (2000). The eclectic paradigm as an envelope for economic and business theories of MNE activity. International business review, 9(2), 163-190.

Dunning, J.H. (2014). Location and the multinational enterprise: a neglected factor?. In Location of international business activities (pp. 35-62). Palgrave Macmillan, London.

Dunning, J.H. (2015). The eclectic paradigm of international production: a restatement and some possible extensions. In the Eclectic Paradigm (pp. 50-84). Palgrave Macmillan, London.

Dunning, J.H., \& Kim, C., \& Park, D. (2008). Old wine in new bottles: a comparison of emergingmarket TNCs today and developed-country TNCs thirty years ago. The rise of transnational corporations from emerging markets: Threat or opportunity, 158-180.

Economic Structure and Context: Demographics and Labor Markets. (2011). Oman Country Monitor. Business Source Premier. Oman: EBSCOhost. p15.

Economy. (2007). Background Notes on Countries of the World. Business Source Premier. Oman: EBSCOhost: P5-7.

Faeth, I. (2009). Determinants of foreign direct investment-a tale of nine theoretical models. Journal of Economic Surveys, 23(1), 165-196.

Fillat-Castejón, C., \& Francois, J.F., \& Woerz, J. (2008). Trade through FDI: investing in services. IIDE Discussion Paper, No. 200805-02.

Forstenlechner, I., \& Rutledge, E.J. (2011). The GCC's "demographic imbalance: Perceptions, realities and policy options. Middle East Policy, 18(4), 25-43.

Gulf Business. (2001). Oman SWOT Report: Private sector led growth is one way. but is Oman ready, 5(9), 46-51.

Ibrahim, O.A., \& Abdel-Gadir, S.E.M. (2015). Motives and determinants of FDI: A VECM analysis for Oman. Global Business Review, 16(6), 936-946.

Lim, S.H. (2008). How investment promotion affects attracting foreign direct investment: Analytical argument and empirical analyses. International Business Review, 17(1), 3953.

Mellahi, K., \& Guermat, C., \& Frynas, J.G. \& Al-Bortmani, H. (2003). Motives for foreign direct investment in Oman. Thunderbird International Business Review, 45(4), 431-446.

Metwally, M.M. (2004). Impact of EU FDI on economic growth in Middle Eastern countries. European Business Review, 16(4), 381-389.

Mina W. (2007). The location determinants of FDI in the GCC countries. Journal of Multinational Financial Management, 17(4), 336-348.

Moosa, I.A. (2009). The determinants of foreign direct investment in MENA countries: an extreme bounds analysis. Applied Economics Letters, 16(15), 1559-1563.

Mukim, M., \& Nunnenkamp, P. (2012). The location choices of foreign investors: A district-level analysis in India. The world economy, 35(7), 886-918.

Narula, R., \& Dunning, J.H. (2000). Industrial development, globalization and multinational enterprises: new realities for developing countries. Oxford development studies, 28(2), 141-167.

National Centre for Statistics Information (NSCI). (2014). Omanis Working in the Private Sector Registered with Public Authority for Social Insurance by Gender and Age Group.

Pantelidis P. \& Nikolopoulos E. (2008). FDI attractiveness in Greece. International Advances in Economic Research, 14(1), 90-100.

Pauceanu, A.M. (2016). Foreign Investment Promotion Analysis in Sultanate of Oman: The Case of Dhofar Governorate. International Journal of Economics and Financial Issues, 6(2), 392-401.

Sadik, A.T. \& Bolbol, A.A. (2001). Capital flows, FDI, and technology spillovers: evidence from Arab countries. World Development, 29(12): 2111-2125. 


\section{Appendix}

Table A1

For Oman and other Regions

\begin{tabular}{l|llll}
\hline Regions & Macro Indicators & 2016 & 2017 & 2018 \\
\hline \multirow{3}{*}{ OMAN } & FDI Inflow & 1.62 & 1.17 & 1.51 \\
& GDP & 195 & 162.3 & 171.46 \\
& IFPI & 27.30 & 23.87 & 29.62 \\
GCC & FDI Inflow & 50.5 & 54.5 & 54.86 \\
& GDP & 3200 & 3300 & 2872 \\
& IFPI & 51.87 & 54.69 & 64.26 \\
ASIA & FDI Inflow & 49.6 & 50.25 & 51.53 \\
& GDP & 2700 & 2900 & 3100 \\
& IFPI & 60.38 & 57.38 & 55.92 \\
EU & FDI Inflow & 595.9 & 835.2 & 725.8 \\
& GDP & 17900 & 18300 & 20900 \\
& IFPI & 109.42 & 151.15 & 116.83 \\
WORLD & FDI Inflow & 2300 & 2340 & 2360 \\
\hline Nof & GDP & 75600 & 77500 & 79400 \\
\hline
\end{tabular}

Notes: FDI \& GDP data is obtained from UNCTAD data base and converted in \$billion. IFPI stands for Inward FDI performance Index.

IFPI is calculated by dividing the ratio of region's FDI inflow to world FDI inflow by the ratio of region's GDP to world GDP.

Table A2.

Economic Freedom Sub-Indices: Oman's Score 2016-2018

\begin{tabular}{cccc}
\hline & & Oman's Score & \\
\cline { 3 - 4 } Economic Freedom Sub-Indices & 2016 & $\mathbf{2 0 1 7}$ & 2018 \\
\hline Overall Score & 66.7 & 67.08 & 62.13 \\
\hline Business Freedom & 68.4 & 70.1 & 68.4 \\
\hline Fiscal Freedom & 98.5 & 98.5 & 99 \\
\hline Monetary Freedom & 76.2 & 77.9 & 80.61 \\
\hline Financial Freedom & 60 & 60 & 60 \\
\hline Trade Freedom & 76.8 & 85 & 85.18 \\
\hline Investment Freedom & 65 & 70 & 65 \\
\hline Labor Freedom & 76.1 & 72.5 & 70.33 \\
\hline Government Spending & 44.2 & 36.8 & 20.5 \\
\hline Freedom from corruption & 47 & 45 & 45 \\
\hline Property Rights & 55 & 55 & 60.8 \\
\hline
\end{tabular}

Note: Oman's score is retrieved from World Economic Forum, The Global Competitiveness Report 20172018 
Table A3.

Ease of Doing Business Sub-Indices: Oman's Rank

Ease of Doing Business (EDB) Sub-Indices

Oman' Rank

(2018)

\begin{tabular}{cc}
\hline EDB overall Rank & 66 \\
\hline Registering Property & 35 \\
\hline Getting Credit & 133 \\
\hline Dealing with Construction permits & 52 \\
\hline Economic Stability & 32 \\
\hline Enforcing Contracts & 60 \\
\hline Paying Taxes & 12 \\
\hline Trading Across Borders & 67 \\
\hline Protecting Investor & 118 \\
\hline Getting Electricity & 69 \\
\hline Resolving Insolvency & 94
\end{tabular}

Note: Oman's rank is retrieved from World Economic Forum, The Global Competitiveness Report 2017-2018

Table A4.

Dunning Model Sub Instruments' Ranking \& Index

\begin{tabular}{ccc}
\hline Oman Characteristics/Dunning Model Sub Instruments & $\begin{array}{c}\text { Friedman's Mean } \\
\text { Rank* }\end{array}$ & $\begin{array}{c}\text { WEF Index } \\
2018^{* *}\end{array}$ \\
\hline Law and order situation & 14 & 27 \\
Political stability & 13 & 19 \\
Tax incentives & 13 & 6 \\
Social climate & 13 & 21 \\
Corruption & 12 & 11 \\
Banking system & 11 & 51 \\
Infrastructure & 10 & 36 \\
Industrial development policies & 10 & 75 \\
Business operating cost & 10 & 48 \\
Macroeconomic outlook & 9 & 66 \\
Institutional standards & 9 & 28 \\
Skilled labor access & 9 & 60 \\
Labor cost & 8 & 73 \\
Foreign markets access & 8 & 62 \\
Profit maximization opportunities & 8 & 47 \\
Business friendly environment & 7 & 18 \\
Exporting terms and conditions & 7 & 66 \\
Local market access & 7 & 62 \\
Investment opportunities & 7 & 53 \\
Government role and policies & 6 & 46 \\
\hline
\end{tabular}

Source: $(*)$ Writer's Calculation from Survey Data

(**) Retrieved from World Economic Forum, The Global Competitiveness Report 2017-2018 